\title{
BRAND RESURRECTION: A STUDY ON DETERMINANTS OF REVIVING DEAD BRANDS IN A EMERGING ECONOMY
}

\author{
Kaushik Handique \\ Research Scholar, Department of Business Administration, \\ Gauhati University, India \\ Dr. Samir Sarkar \\ Assistant Professor, Department of Business Administration \\ Gauhati University, India
}

\begin{abstract}
With the technological advancement, rapid pace of innovation and changing customer taste and preference, the normal life expectancy of many brands have declined unpresidently in the the marker in $21^{\text {st }}$ century. This uncertainity is facing by almost all brands in the world irrespective of their current and past market size. The survivability of the brand or the longevity of the PLC is highly depends on how successfully these brands can touch their customers emotionaly, connects their inner selves and find new ways to reconnect. Mostly those brands vanish which fail to deliver a conctrete value to the customer and are very rigid in their approaches. Customers are more connected with the intangible attributes rather than physical or tangible attributes. Marketers must not forget that if a brand vanish or fail in a market, it must be because of certain specific and a number of other secondary factors. Changing trends or a poor marketing plan can also be a reason prime reason for any failure in the success. So, it could imply that a brand can return back strongly at any time if it gets proper timing, suitable trend and fashion. We have quite a few evidence that a few brands have effectively restored their names and revitalized their brands. Ultimately, a brand seeking to shed its past mistakes and forge ahead needs to examine its brand story to decide what connective elements should be carried forward, and what should be left behind.
\end{abstract}

But there is a little research done in the area related to understanding the consumer desire to participate in brand resurrection and its ever-growing importance (Cattaneo, 2012; Dion, 2016). The study highlights the fact that several dead brands are being revived or are in the process of revival by organizations due to consumerbrand co-creation and resurrection movements.

The main objective of the study is to explore factors that drive consumer participation in resurrection. The design of the research can be classified as both 
descriptive and exploratory; a survey method using a structured questionnaire is being used for data collection. The results of the study indicate that functional and social-adjustive utilities along with perceived brand superiority are not significantly associated with participation in brand resurrection. Further, we find partial support for the moderating effect of nostalgia. The relationship between functional and socialadjustive utilities and participation in brand resurrection is significant when moderated by nostalgia. The relationship between value-expressive utility and participation in brand resurrection is significant. There is a significant interplay between the value-expressive utility and nostalgia which suggests that both intentional and unintentional factors can explain customer motivation to participate in brand resurrection. Finally, the result indicates that nostalgia positively moderates all the factors like functional utility, social-adjustive utility, value- expressive utility, and brand superiority of a brand towards the resurrection movement. To the authors' knowledge, this is the first study to provide a more comprehensive look at the factors that can determine brand resurrection in Indian and Northeast Indian Context.

Key words: functional utility, social-adjustive utility, value- expressive utility, brand superiority, brand resurrection

Cite this Article: Kaushik Handique and Samir Sarkar, Brand Resurrection: A Study on Determinants of Reviving Dead Brands in a Emerging Economy, International Journal of Management, 11(12), 2020, pp 1075-1089.

http://iaeme.com/Home/issue/IJM?Volume=11\&Issue $=12$

\section{INTRODUCTION}

In the past a few years, a number of once-dead brands have been restored back to life. From a marketing point of view, it has always been a difficult decision to say retire a brand, but due to poor performance, it is often seen that companies disolve some brands from their brand portfolios. It can also be seen that marketers sometimes bring those dead brands back at a later time. While we can say resurrecting a brand is odd enough from a strategic, organizational, and portfolio perspective, but the driving force behind these recent resurrections is even more bewildering. There have been many instances where consumers did not buy enough of a particular brand due to which the brand get retired from the organization's portfolio but years later the same consumers demand its comeback. For example, Cadbury Wispa was discontinued in 2003 but was again brought back to the market in 2008 and sold 41 million bars in the first 18 weeks of re-launch(Souce). VolksWagen Beetle was very famous in the early 1970s but gradually its popularity went down until 1993. However, the dominance of retro fashion brought back demand for the Beetle, so VW designed a new model in 1998 (2016, p. the telegraph). Coca-Cola Surge, which was discontinued in 2002, was brought back to the market again in 2014 after more than 200,000 people joined a Facebook page named "Surge Movement" and rallied to bring back the brand (Moye, 2018). Similarly, Crystal Pepsi was resurrected at the end of 2015, and fully re-launched in Canada and the USA during the summer of 2016. This is because Crystal Pepsi fans and celebrities, including "LA Beast" who has more than 1.2 million subscribers to his YouTube channel and Kevin Strahle YouTube celebrity and competitive eater, led the \#BringBackCrystalPEPSI social media campaign (Tesema, 2016). Most recently, Cellular Mobile brand Nokia re-launched its iconic 3310 phones in response to consumers' interest in simplicity and longer battery life. (Jussi Rosendahi, 2017). Nokia itself is a brand that is resurrected by Micosoft. In India, brands like Royal Enfield and Jawa are popular examples of this resurgence movement.

It is seen that from a consumer's perspective the taking away of well-linked brands symbolizes withdrawal of their freedom of choice and results in increased affinity for such 
brands. (Brehm, 1966) Consumers' implied need to reclaim their choice and the power of newer media, especially social media, has given to the opportunities for consumers a channel to demand their beloved brands back. This is also in part due to the growing significance that companies give to value co-creation (Iglesias, 2013). This movement of consumers coming together to demand the re-launching of dead brands is as brand resurrection (Davari, A., Iyer, P. and Guzmán, F. ,2017).

The buyer's power is the main impetus behind the resurrection of the old brands. They assume a prominent role in launching a significant portion of these brand revival developments utilizing web-based social networking. Shoppers' convictions and trust about the utilitarian and value expressive utilities and their decisions of the apparent brand predominance of the outdated brand are fundamentally connected with brand revival or resurrection movement.

Nostalgia additionally controls the connection between social-adjusted utility and brand resurrection movement, which shows that customer's social-adjusting utility, becomes applicable when activated with a solid feeling of the past (Davari, A., Iyer, P. and Guzmán, F. ,2017).

Marketers consistently attempt to discover better approaches to ask what their brands mean to customers. Another way of expressing this inquiry is the focal point of this examination: What can consumers (and their recollections) uncover about brand meaning? By distinguishing the whole consumer self in correspondence to a given item or brand, advertisers can reveal amazing, passionate methods for association (reconnection) their brand image to the buyer. Managers always try to find new ways to ask what their brand means to consumers (Arezoo Davari, 2017).

The significance of understanding the variables driving a brand revival movement is featured in the way that these brands frequently hold lingering or residual value - for example, customers may at present have elevated levels of brand awareness and positive brand image (Thompson, 2008). This residual value shows some degree of inactive positive brand impact of the consumers toward the brand, which can be exploited by organizations to both engage consumers at a more profound level and increment profits. Frequently named as "zombie brands" (Schlossberg) these brands consistently stay in the minds of consumers tending to the concern of awareness - and hold a degree of proclivity that few existing brands can match (Ewing, Jevons \& Khalil, 2009).

(O'Reilly, 2016), This is also a very interesting fact that several of these brands were removed because of poor brand management in organizations, as opposed to consumer dismissal. Of course, several organizations are progressively taking advantage of this fact by presenting a more refreshed and more up-to-date version of the defunct brands - either their self owned dead brands or ones that have been bought from different organizations.

This research aims to investigate the factors that drive consumers' contribution to brand resurrection - an outcome of brand co-creation. As such, the finding will address the gap in understanding the factors that are leading to the ever-growing brand resurrection.

\section{REVIEW OF LITERATURE}

\subsection{Brand Resurrection}

A brand get retired not only because of the poor strategy of any organization but also due to the pre-matured launch, insuitable time, prevailing fashion and trends. (Ewing, 2009) contend that the demise of a brand isn't really just because of the management incompetence yet in addition in light of the normal formative procedure of a brand and the evolving social- 
adjustive utilities that buyers get from the brand. (Kumar, 2003) express that retiring a brand is a vital procedure to enhance the brand portfolio given that most brands don't bring in cash.

The developing power of consumers and the consideration on brand co-creation, these two elements center on brand revivals from the customers' point of view and characterizes a brand resurrection movement as the procedure that is started by buyers to breathe life back into a dead brand.

Most of the recent consumer-driven brand resurrections have been begun through social media. It seems to be only natural as (Iglesias O. a., 2012) posts that consumers co-create brand identities going through their daily usage of social networks. (Vallaster, 2013) Argue that co-creation dynamics are authorized by the opportunities that virtual spaces provide for consumer interaction. Authors explore consumer motivations to co-create, and find that consumers engage in co-creation when it affects their social life, they find it is fun, they feel a certain degree of value similarity with the brand, they find the brand's communication engaging and they feel a certain degree of commitment towards the brand (Hsieh, 2016). Thus, all these motivating factors provide some level of utility to the consumer. If a brand is brought back to life due for consumer power or pressure, then the brand resurrection movement can be considered an outcome of consumer-brand co-creation. Past researcher explores the motivations - functional utility, value-expressive and social-adjustive utilities brand associations and brand knowledge behind the resurrection of a brand (Cattaneo and Guerini, 2012; Thompson, 2008). Although several motives and beliefs may be influence brand resurrection, this study specifically examines motivations relates to utilities functional, value-expressive and social-adjustive - along with the perceived brand superiority of a defunct brand. Brands offer buyers to satisfy functional, value-expressive and socialadjustive utilities (Grewal, 2004). In today's challenging environment, brand superiority judgments - for example regardless of whether a dead brand is better than the currently accessible other options - are easily prompted. Moreover, (Brown, 2003) and (Cattaneo, 2012) are identify nostalgia is a key factor for revitalizing defunct brands and argue that nostalgia might call up positive associations towards defunct brands. Nostalgia may enhance the relationships among the perceived utilities and the desire to resurrect a brand and it thus considered as a moderator.

\subsection{Brand Utilities}

Customers form perceptions about brands based on their utilities. Brands may fulfill basic functions, be used to communicate one's self to others (social-adjustive) and fulfill hedonic goals. Functional utility refers to the practical benefits of brands that are often tangible (Bhat, Symbolic and functional positioning of brands", , 1998) (Geiger-Oneto, 2013). Functional utilities include physical attributes, design and features (Stokburger-Sauer, 2013) . Functional utilities are important because they form the core benefit of several brands. When brands conclude to perform the functional utility, consumers overlook them in their purchases (Thompson, 2008). As for example, water brands such as Dasani or Aquafina might be considered to satisfy the functional need of quenching consumers' thirst.

\subsection{Value-Expressive Utility}

Value-expressive utility refers to the hedonic benefits that a brand offers. Specifically, it refers to the fantasy, fun and other hedonic associations of a brand (Hirschman, 1982). Valueexpressive utility is subjective and it includes the expression of a consumer's central values to others (Grewal, The timing of repeat purchases of consumer durable goodsthe role of functional bases of consumer attitudes", 2004). For example, consumers might opt for Evian bottled water to obtain a feeling of achievement, pleasure, luxury and hedonic pleasure. These 
consumers expect to fulfill more than just the functional need of thirst when they consume Evian.

\subsection{Social-adjustive Utility}

Social-adjustive utility looks at the fulfillment provided by the brands in a social context. It is well established in the nonfiction that brands provide some degree of social-adjustive utility (Bhat, 1998). Social-adjustive utility helps consumers to fit into social situations Grewal 2004. Consumers tend to overlook the functional utilities of brands having a outstanding social-adjustive utility (Bhat, 1998). Social-adjustive utility is mostly created through the meanings and associations, not through the core benefit of the brand itself (Keller K., 1993). For example, a person who is environmentally conscious might drink Starbucks' Ethos water to portray an image of being socially responsible to others. In summary, consumers may attribute these various utilities to defunct brands based on the current competitive environment and their unmet need.

All brands have some combination of functional, value-expressive and social-adjustive utilities. Furthermore, nostalgia and brand judgments are important drivers for reviving failing brands (Brown, 2003). Extending this logic to the context of invalid brands, this study argues that consumers develop reasons for their associations with invalid brands, as these brands are no longer available in the market. Consumers' intentional and unintentional reasons for participating in brand resurrection may be driven by the defunct brands' utilities, along with their perceptions of the defunct brand's superiority, and finally affected by current market conditions and the effect of nostalgia. Value expressive and social-adjustive utilities are more driven by associations pertaining to the hedonic gratification and social objectives satisfaction, respectively. These utilities constitute the subjective reasons for participating in brand resurrection. So both these utilities are co-created by consumers and are mostly intangible in nature. Therefore, although several brands may be able to fulfill the functional utility of the defunct brands, value-expressive and social-adjustive utilities are more complex to fulfill compare to others. These utilities are not necessarily based on past experiences, but could have been trickled-down to younger generations by word-of-mouth. For example, consumers wanted to bring back Coca-Cola Surge, despite the presence of several alternative brands having the same functional utility.

\subsection{Brand Superiority}

Another factor influencing brand resurrection is consumers' observations of the superiority of the defunct brands. Keller (2003, pw. 68) defines brand superiority as "the extent at which customer views the brand to be unique or better than other brands". Brand superiority is the result of individuals' judgments of brands and their meanings (Keller K. , 1993). (Keller K. , 2003) consumer-based brand equity model launches that loyalty(resonance) is the ultimate step to establish a strong brand. However, resonance itself is a derivative of several rational and emotional associations with a brand. Loyalty can only be Brand resurrection movement built at the point when a brand creates unique feelings and associations that lead to customers' perceptions of the brand being better than its competitors. Therefore, brand superiority is essential to building deep and lasting relationships with customers (Keller K. , 2003)

Brand superiority is a combination of subjective and rational reasons, which denotes some degree of unmet needs those present in the market, and is critical to build a long-lasting relationship with consumers. Perceptions of brand superiority may measure the consumers' desire to remain loyal to a brand. Hence, consumers who have strong perceptions of defunct brands' superiority may actively participate in bringing them back to life. 


\subsection{Nostalgia}

Nostalgia can produce strong responses from consumers for defunct brands. Brands connected to a consumer's past produce a strong feeling of nostalgia. As per (Holak, 1998) Nostalgia is defined as "a longing for the past, a yearning for yesterday, or a fondness for possessions and activities associated with days of yore". Extant literature said nostalgia as an important factor in the revival of a failing brand. As per (Belk, 1991) Nostalgia can be aroused when individuals are presented with objects from the past. (Cohen, 2004) said that this arousal can lead to the polarization of motivations, this may affect how customers evaluate the defunct brands. Consistent with this line of thinking, argues that objects that are nostalgic, help an individual define their self, performance and values. Thus, when consumers miss a defunct brand, nostalgia plays a key role in attractive consumers' perceptions of the utilities of a defunct brand. Nostalgia evokes past feelings associated with the brands, leading to stronger consumer perceptions of defunct brand utilities. Nostalgia is a situational factor and so represents the unintentional reason behind the participation in brand resurrection. In the effect of nostalgia as an interacting variable, consumers are swept to better and happier days, resulting in more positive moods. This, in turn, leads to more positive perceptions about the defunct brands (Putrevu, 2014). The nostalgic feelings toward a defunct brand - and/or in this case, the technology - may enhance consumers' desire to resurrect it. Previous literature on consumer behavior also satisfy that moods/emotions generally play a role in enhancing or weakening the consumer responses to brands (Puccinelli, 2015)

\section{RESEARCH GAP}

Old-fashioned brands are re-launched as historical brands with refreshed features. Retro brand meanings are conjecture on a perfect collective component and an intriguing paradoxical essence (Dion, Delphine \& Mazzalovo, Gerald. 2016). Retro brand management involves an uneasy, co-creative, and occasionally excited alliance between producers and consumers. The ascent of retro brands places marketing is an engrossing hypothetical dilemma. From one perspective, marketers have ceaselessly incited the requirement for product differentiation, so that the present market environment can create interest for solid brand identities and denounces impersonation. But then again, current markets are also engulfed with refreshed impersonations, for example, retro brands, huge numbers of which are demonstrating tremendously popular (Eleonora Cattaneo, 2012).

To more readily comprehend the elements which drive consumers' motivations/attitudes to participate in brand resurrection, the researcher borrow from the literature of the functional bases of attitudes (Eagly, 1993). In light of the extant literature, consumers hold various attitudes (functional, value-expressive and social-adjustive), and they serve as the knowledge function that permits customers to sort out and structure data about an item/brand (Grewal, 2004). These attitudes are associated with the different utilities given by brands. Utilitarian utilities discuss substantial, practical advantages of brands. Value-expressive utilities refer to impalpable, epicurean benefits of brands. Finally, social-adjustive utilities represent the social delight provided by brands.

As the expanding significance of understanding the buyer's intent in participating in brand resurrection, we see that there is still a little research here (Cattaneo, 2012; Dion, 2016). While the associations of these various types of attitudes and brand perceptions have been surveyed in the literature, the associations among these attitudes and aim to participate in brand resurrection need to be investigated, as dead brands are often considered to be deficient in one or more of these utilities. Furthermore, the earlier studies in this area were based on developed countries. Therefore, the earlier results may not hold in developing country settings where the economy is characterized by weak institutional environments, poor enforcement of 
law, bureaucratic complexity and red tape, social insecurity and corruption; the concept of environmental consciousness and its practices may come to the forefront with a very different meaning (Jamali and Mirshak 2007). Indian markets have been a greenfield for this new concept and the proposed study will explore and enhance the understanding of a marketer in this area which would be responsible for increasing the profitability of the brands and their associated products.

\section{OBJECTIVES OF THIS STUDY}

From a managerial point of view, the investigation gives understanding into when and how organizations can think about bringing back dead brands. This study will empirically examine the inspirations driving customer support in bringing back dead brands. The significance of this study is featured in the way that a few outdated brands are being resuscitated by organizations because of consumer brand co-creation movements. The main objective of the study is to explore factors that drives consumer participation in resurrection movement.

\subsection{Research Hypothesis}

H1: Functional utility of the defunct brand is positively associated with the participation in brand resurrection.

H2: Social-adjustive utility of the defunct brand is positively associated with the participation in brand resurrection.

H3: Value-expressive utility of the defunct brand is positively associated with the participation in brand resurrection.

H4: Perceived brand superiority of defunct brands is positively associated with the participation in brand resurrection.

H5: Nostalgia will positively moderate the relationship between (a) functional utility, (b) social-adjustive utility and (c) value-expressive utility and (d) participation in brand resurrection.

\subsection{Theoritical Framework:}

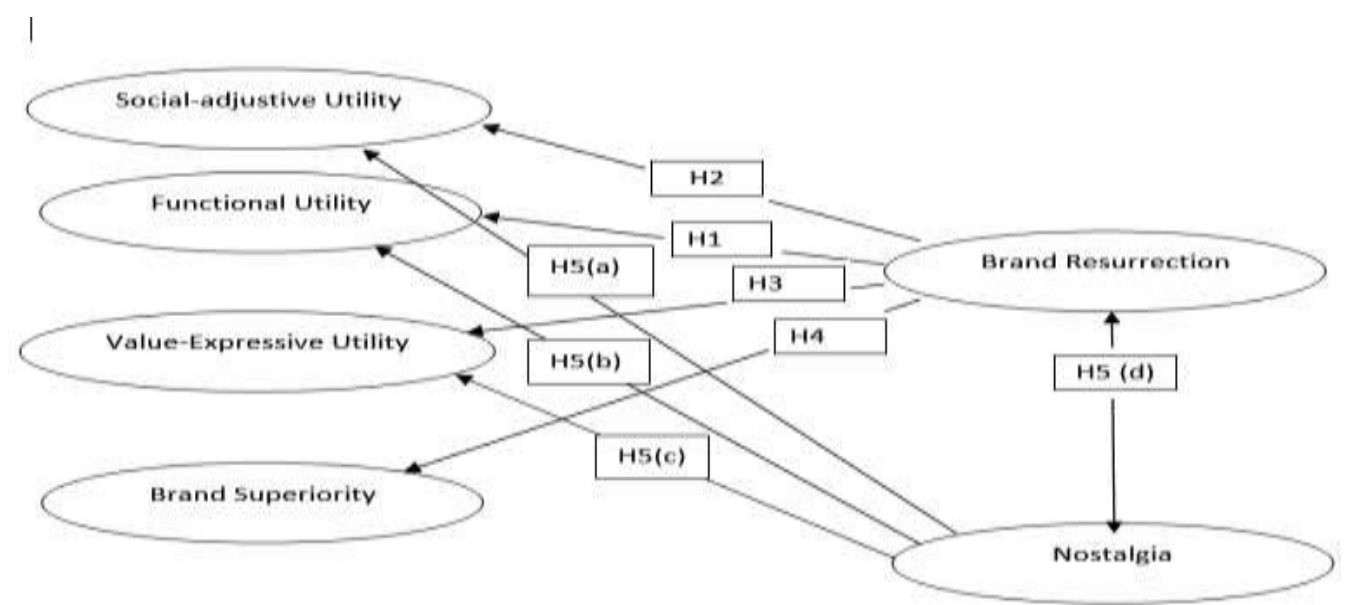

Figure 1

\section{METHODOLOGY}

The design of the research can be classified as both descriptive and exploratory in nature; a survey method using structured questionnaire was carried out for data collection. Data were collected through a survey of 400 millennial respondents using Non-probability Judgement 
Sampling and out of which 385 millennial respondents were retained who were qualified for data collection. Anyone born between 1981-1996 is considered a Millennial. (Dimock, 2019). Millennial consumers are, therefore, an appropriate population to engage with, to study brand resurrections, given their role as primary actors behind these campaigns and their high levels of social media usage and digital engagement. In this research paper, the study is carried on the urban agglomerations/cities of Assam. The sample frame is selected with context to Tier I, Tier II and Tier III cities. In this paper, only three Tier I cities of Assam are being considered. The internal consistency and construct validity was established using confirmatory factor analysis. Finally, predictive validity was established by testing the research model. Considering the objectives of the study, structural equation modeling (SEM) was used to analyze the data.

The four variables of brand resurrection were used in the research was adopted from (Kumar, 2003; Ewing, 2009); The four variables of Functional utility ,three variables of value-expressive utility and five variables of social-adjustive utility from (Cattaneo, 2012) and (Thompson, 2008); the five variables for brand superiority (Keller K. , 1993; Keller K. , 2003); and seven variables from nostalgia (Holak, 1998) were measured for the study.

The respondents were asked to recollect the reasons they missed the brands. These reasons were captured in the form of nostalgia, functional, value-expressive, social-adjustive utility and perceived brand superiority, which measured the degree to which the respondents were not loyal to current alternatives for the brand. Variables were measured by using five-point Likert scale.

\section{ANALSYIS AND FINDINGS}

\subsection{Reliability Statistics of the variable}

Table 1

\begin{tabular}{|l|c|c|}
\hline \multicolumn{1}{|c|}{ Measures } & Number of items & Cronbach's Alpha \\
\hline Functional utility (FU) & 4 & .846 \\
\hline Social-adjustive utility (SAU) & 5 & .881 \\
\hline Value-expressive utility (VEU) & 3 & .853 \\
\hline Brand-superiority (BS) & 5 & .841 \\
\hline Nostalgia (NG) & 7 & .925 \\
\hline Brand resurrection movement (BRM) & 4 & .773 \\
\hline
\end{tabular}

\subsubsection{Total Reliability statistics of the variable}

Table 2

\begin{tabular}{|c|c|}
\hline Cronbach's Alpha & Numbers of Items \\
\hline .940 & 28 \\
\hline
\end{tabular}

These values excellently support the internal reliability of the questionnaire, because the calculated results for Cronbach's alpha is more than 0.9 hence the statistic of the respective emergent factors was found to be excellent. Hence, the questionnaire i.e. being used for the survey is reliable.

\subsection{Descriptive Statistics}

Descriptive statistics depicted that (51.6\%) respondents were male, $(47.2 \%)$ were female and $(1.3 \%)$ belonged to Other category. The sample is almost equally representative of both Male and Female category. (3.4\%) respondents were of age less than 20yrs, (56.2\%) respondents were of age $20-25 y r s,(30.1 \%)$ respondents were of age $26-30,(7.5 \%)$ respondents were of 
age $31-35 \mathrm{yrs},(2.3 \%)$ respondents were of age $36-40 \mathrm{yrs},(0.5 \%)$ respondents were more than $40 \mathrm{yrs}$ of age. Hence we observe the majority of respondents lies between the age 20-30 yrs of age. $12.2 \%$ of the respondents are in business, $10.1 \%$ of the respondents are self employed, $32.4 \%$ of the respondents are in service, $41.2 \%$ of the respondents are students and $4.1 \%$ of the respondents are unemployed.

\subsection{The Resurrection Model}

Model fit is determined by comparing how closely the estimated covariance matrix match the observed (sample) covariance matrix S, Model identification concerns whether there is enough information in the covariance matrix to enable us to estimate a set of structural equation. Goodness-of-fit indices indicate how well the specified model fit the observed or sample data, and so higher values of these measures are desirable.

Table 3 The fit values of modification

\begin{tabular}{|l|c|c|}
\hline \multicolumn{1}{|c|}{ Goodness of fit index } & Absolute fit value & Acceptable fit \\
\hline Chi-square $\left(x^{2}\right)=$ CMIN & 930.954 & \\
\hline Degree of freedom & 315 & $1-5$ \\
\hline Chi-square/sq & 2.955 & $0.90 \leq \mathrm{GFI} \leq 0.95$ \\
\hline GFI & .845 & $0.85 \leq \mathrm{AGFI} \leq 0.90$ \\
\hline AGFI & .814 & $0.05 \leq \mathrm{RMSR} \leq 0.80$ \\
\hline RMSR & .075 & $0.05 \leq \mathrm{RMSEA} \leq 0.80$ \\
\hline RMSEA & .071 & \\
\hline \multicolumn{2}{|c|}{ Increasing fit value } & $0.95 \leq \mathrm{CFI} \leq 0.97$ \\
\hline CFI & .902 & $0.95 \leq \mathrm{TLI} \leq 0.97$ \\
\hline NNFI=TLI & .891 & $0.95 \leq \mathrm{NFI} \leq 0.97$ \\
\hline NFI & .860 & \\
\hline
\end{tabular}

(Chi-square test gives the difference between the observed data and the estimated data. This value expected to be close to 0 . However, in case the number of sample is big, the degree of freedom is an important criterion $. \mathrm{X}^{2} /$ sd ratio's being 5 or less than 5 shows that there is a good fit between the model and datum) (Naresh K. Malhotra, 2018). In this research the ratio was calculated to be 2.955. This result shows existence of a very good fit between the data and the model. The value of the GFI and AGFI are .845 and .814 which is slightly below the acceptable range. On the other hand the value of RMSR and RMSEA are .075 and .071 which is perfectly fit for the model. These result shows that the model is absolute fit Indices but it badness of fit. These are because this topic is new for the researcher so there may be an exogenous variable present in this study. An exogenous construct is determined by factors outsides the model and the researcher fail to explain in these model. Further research is required on this topic.

Table 4 Research Variable

\begin{tabular}{|c|c|c|c|c|c|c|}
\hline $\begin{array}{c}\text { Latent } \\
\text { variable }\end{array}$ & Observed variable & 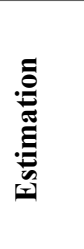 & $\frac{r y}{\dot{s}}$ & $\underset{\overbrace{}}{\stackrel{\mathscr{E}}{\pi}}$ & $\begin{array}{l}\dot{u} \\
\dot{1}\end{array}$ & 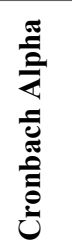 \\
\hline \multirow{4}{*}{ 氖 } & $\begin{array}{l}\text { (FU2)Because it offered } \\
\text { good } \\
\text { Value for money }\end{array}$ & .854 & .064 & 13.451 & .677 & \multirow[t]{4}{*}{.846} \\
\hline & $\begin{array}{l}\text { (FU 3)Because it was } \\
\text { trustworthy }\end{array}$ & .958 & .059 & 16.114 & .792 & \\
\hline & $\begin{array}{l}\text { (FU 4)Because it had } \\
\text { good features }\end{array}$ & .892 & 0.55 & 16.114 & .792 & \\
\hline & (FU 5)Because it had & 1.000 & - & - & .802 & \\
\hline
\end{tabular}


Brand Resurrection: A Study on Determinants of Reviving Dead Brands in a Emerging Economy

\begin{tabular}{|c|c|c|c|c|c|c|}
\hline & excellent quality & & & & & \\
\hline \multirow{4}{*}{ 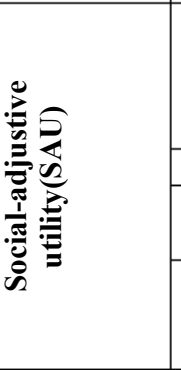 } & $\begin{array}{l}\text { (SAU2)Because it was } \\
\text { important to show my } \\
\text { friends that I used } \\
\text { this brand. }\end{array}$ & 1.000 & - & - & .814 & \multirow[t]{4}{*}{.881} \\
\hline & (SAU 3) Because it used to help me fit into social groups & 1.057 & .053 & 19.760 & .874 & \\
\hline & $\begin{array}{l}\text { (SAU 4)Because I could represent myself to the society by } \\
\text { consuming it }\end{array}$ & 1.048 & .056 & 18.845 & .842 & \\
\hline & $\begin{array}{l}\text { (SAU5) Because it was } \\
\text { a symbol of } \\
\text { my social status }\end{array}$ & 1.094 & .060 & 18.308 & .824 & \\
\hline \multirow{3}{*}{ 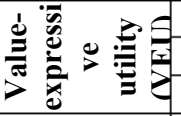 } & (VEU1)Because I could personally feel better after consuming it & .981 & .057 & 17.097 & .815 & \multirow{3}{*}{.853} \\
\hline & (VEU 2)Because I enjoyed buying it & 1.010 & .060 & 16.692 & .796 & \\
\hline & (VEU 3)Because it gave me pleasure to consume this brand & 1.000 & - & - & .827 & \\
\hline \multirow{5}{*}{ 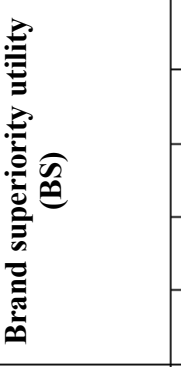 } & $\begin{array}{l}\text { (BS1)If this brand was still available, I would recommend it to others } \\
\text { as opposed to the alternatives. }\end{array}$ & .887 & .070 & 12.615 & .687 & \multirow{5}{*}{.841} \\
\hline & $\begin{array}{l}\text { (BS 2)Despite the lower price of alternatives, I would rather pay } \\
\text { higher price to buy this brand. }\end{array}$ & .890 & .073 & 12.225 & .666 & \\
\hline & $\begin{array}{l}\text { (BS 3)Even though other people consider alternative brands to be } \\
\text { superior, I continue to express that this brand was better. }\end{array}$ & 1.043 & .072 & 14.425 & .790 & \\
\hline & $\begin{array}{l}\text { (BS 4)While the quality of alternative brands may be better, I still } \\
\text { believe that this brand was a superior choice. }\end{array}$ & 1.022 & .077 & 13.286 & .724 & \\
\hline & $\begin{array}{l}\text { (BS 5)Although there are brands that can better meet my needs, I still } \\
\text { miss this brand. }\end{array}$ & 1.000 & - & - & .731 & \\
\hline \multirow{7}{*}{ 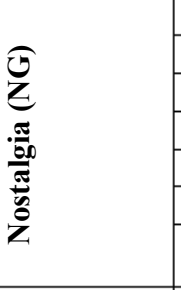 } & (NG1)Reminds me of the past & 1.000 & - & - & .781 & \multirow[b]{7}{*}{.925} \\
\hline & (NG 2)Is a happy reminder of the past & 1.099 & .060 & 18.323 & .842 & \\
\hline & (NG 3)Takes me to the times when I was younger & 1.083 & .062 & 17.338 & .806 & \\
\hline & (NG 4)Helps me recall pleasant memories & 1.119 & .062 & 18.121 & .834 & \\
\hline & (NG 5)Makes me want to go back to those good old days again & 1.037 & .060 & 17.275 & .804 & \\
\hline & (NG 6)Makes me feel nostalgic & 1.127 & .062 & 18.248 & .839 & \\
\hline & (NG 7)Push retailers for bringing this brand back & .798 & .060 & 13.316 & .647 & \\
\hline \multirow{4}{*}{ 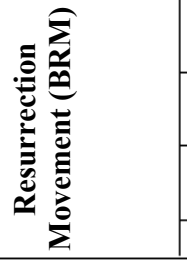 } & $\begin{array}{l}\text { (BRM1)Actively participate in consumer movement toward re- } \\
\text { launching the brand. }\end{array}$ & 1.000 & - & - & .705 & \multirow[t]{4}{*}{.773} \\
\hline & $\begin{array}{l}\text { (BRM 2)encourage others to participate in consumer resurrection } \\
\text { movement }\end{array}$ & 1.204 & .103 & 11.676 & .781 & \\
\hline & $\begin{array}{l}\text { (BRM 3)donating for the consumer movement towards re-launching } \\
\text { the brand }\end{array}$ & .924 & .093 & 9.986 & .607 & \\
\hline & (BRM 4)starting a movement towards bringing back the brand back & .912 & .092 & 9.940 & .604 & \\
\hline
\end{tabular}

S.E $=$ Standard Error, SRC $=$ Standard Regression Co-efficient

Acceptable Value: $T$-value $>1.96$ or $t<-1.96$, S.R.C $=-1$ to +1 , Cronbach Alpha $\geq 0.7$.

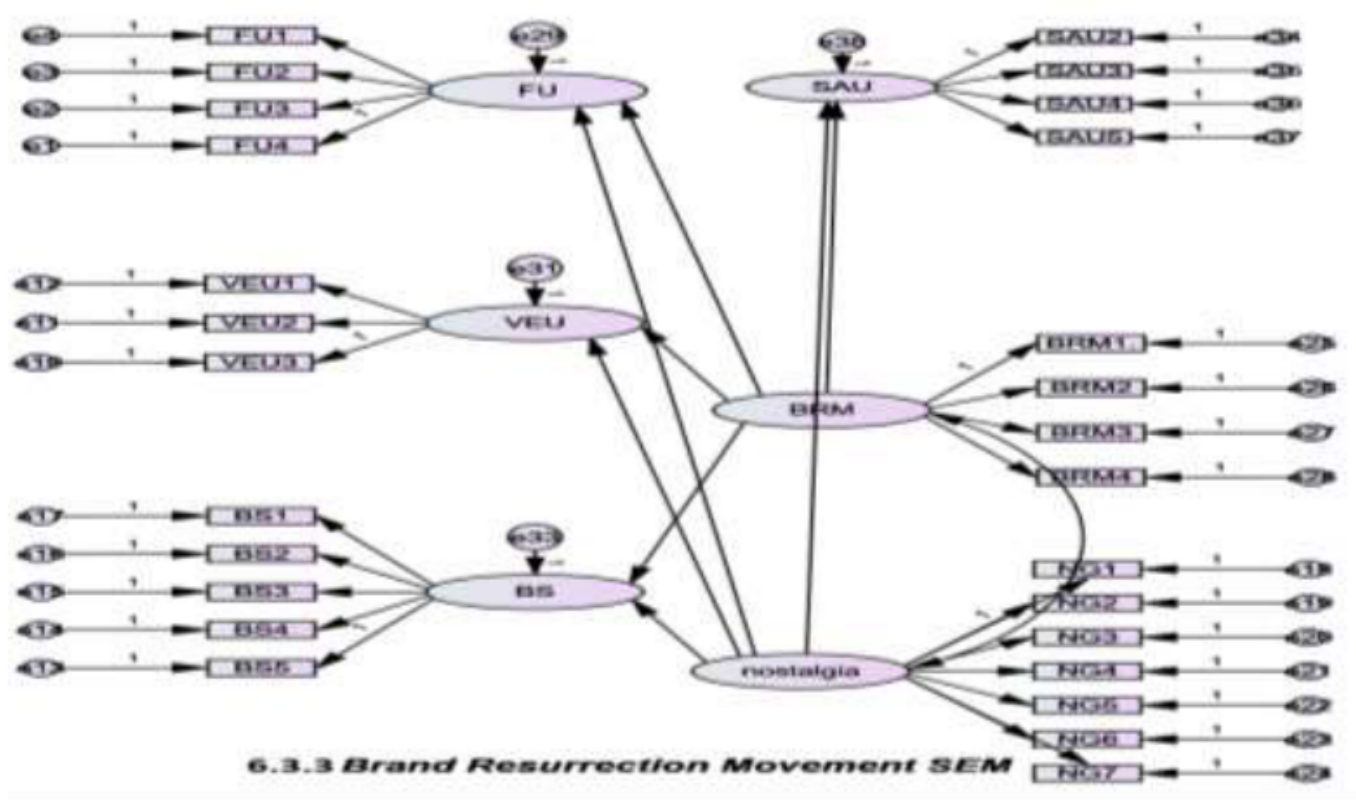




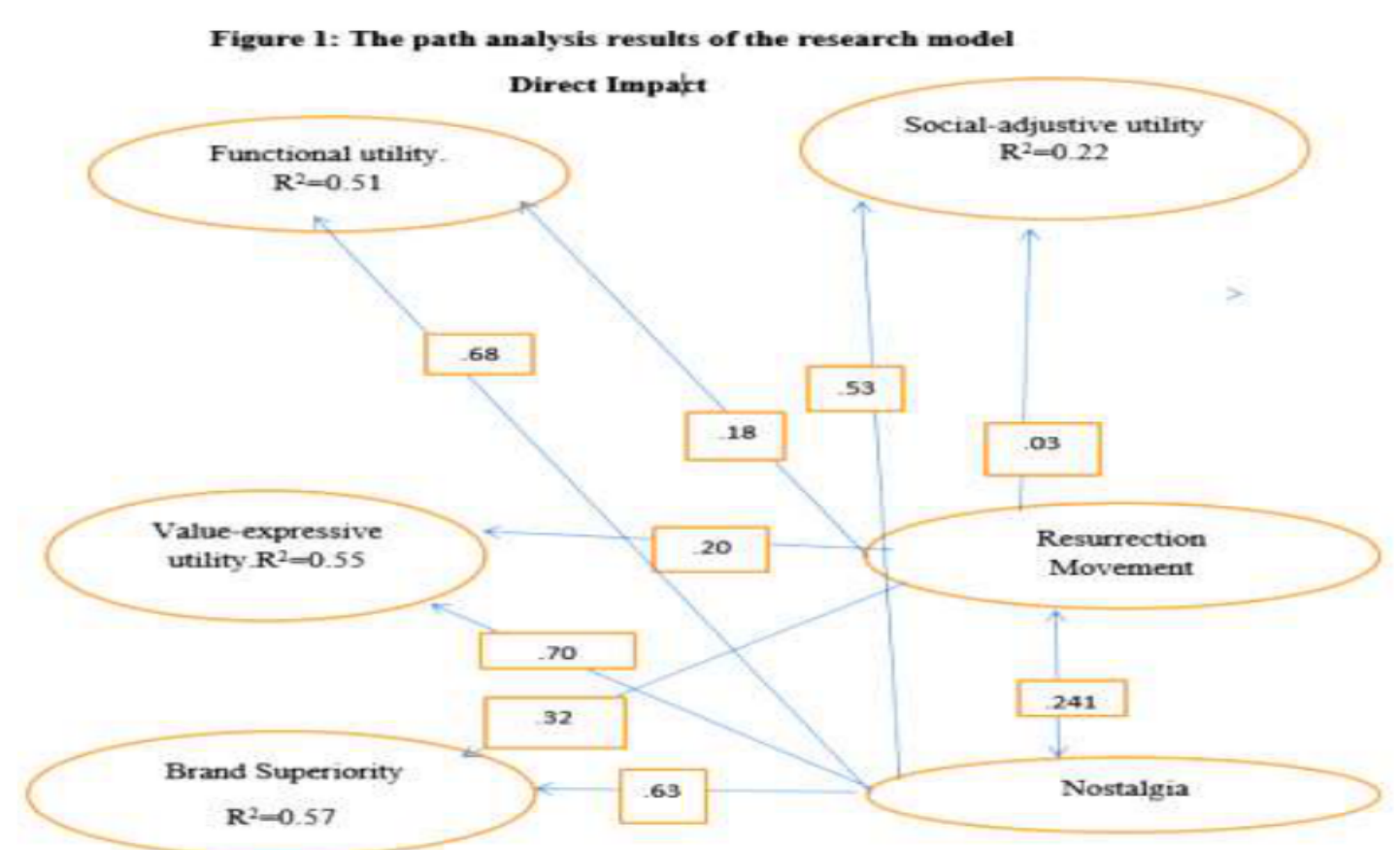

Table 5 Established Values Fit criteria for the Model

\begin{tabular}{|c|c|c|c|c|c|c|c|}
\hline \multirow[b]{2}{*}{ Relationships in the Model } & \multicolumn{6}{|c|}{ Standardized Impact estimation } & \multirow[b]{2}{*}{ 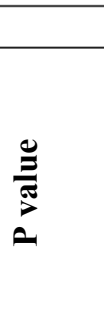 } \\
\hline & 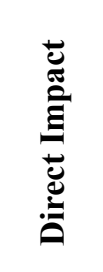 & 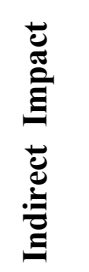 & 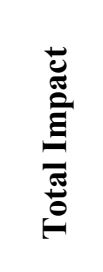 & 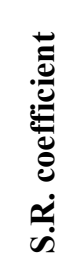 & sis & 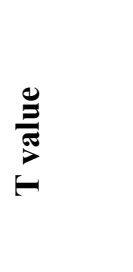 & \\
\hline $\begin{array}{l}\text { Functional Utility-Resurrection } \\
\text { Movement }\end{array}$ & -.182 & - & -.182 & .127 & .072 & -2.535 & .011 \\
\hline Functional Utility-Nostalgia & .720 & - & .720 & .680 & .062 & 11.631 & **** \\
\hline $\begin{array}{l}\text { Social Adjustive Utility- } \\
\text { Resurrection Movement }\end{array}$ & -.026 & - & -.026 & .017 & .086 & -.306 & .791 \\
\hline Social Adjustive Utility-Nostalgia & .527 & - & .527 & .466 & .065 & 8.076 & $* * *$ \\
\hline $\begin{array}{l}\text { Value-expressive Utility- } \\
\text { Resurrection Movement }\end{array}$ & .263 & - & .263 & .181 & .072 & 3.636 & $* * *$ \\
\hline Value-expressive Utility-Nostalgia & .728 & - & .728 & .679 & .061 & 11.980 & $* * *$ \\
\hline $\begin{array}{l}\text { Brand superiority-Resurrection } \\
\text { Movement }\end{array}$ & .320 & - & .320 & .248 & .067 & 4.783 & $* * *$ \\
\hline Brand superiority-Nostalgia & .626 & - & .626 & .654 & .058 & 10.864 & $* * *$ \\
\hline Nostalgia -Resurrection Movement & .097 & - & .097 & .241 & .025 & 3.814 & $* * *$ \\
\hline
\end{tabular}

$S . E=$ Standard Error, $S R C=$ Standard Regression Co-efficient

S.R. $C=-1$ to $+1, T$-value $>1.96$, the $p$-value is a number between 0 and 1

From table 6.3, it is seen that fit criteria have acceptable value except for the relation between functional Utility and resurrection movement and Social adjustive utility and resurrection movement. As a result of the research, it was determined that Value-expressive utility $(\beta=0.181, p=0.000)$, brand superiority $(\beta=0.248, p=0.000)$, and nostalgia $(\beta=.241$, $\mathrm{p}=0.000)$ affected brand resurrection movement and Functional Utility $((\beta=0.127, p=0.011)$ and social-adjustive Utility $(\beta=0.181, p=0.791)$ had no significant effect on Brand resurrection movement. It was determined that Nostalgia moderate over Functional utility $(\beta=0.680$, $p=0.000)$, Social adjustive utility $(\beta=0.466, p=0.000)$, Value expressive-utility $(\beta=0.679$, 
$\mathrm{p}=0.000)$ and brand superiority $(\beta=0.654, \mathrm{p}=0.000)$ positively. As support by literature, valueexpressive utility, brand superiority and nostalgia encourage consumers for the brand resurrection. Nostalgia have positively moderate effect on Functional utility, Social adjustive utility, Value expressive utility, brand superiority and resurrection movement. In other cases functional utility and social adjustive utility have no impact on resurrection movement. The results of the research hypothesis in the direction of the explanation as follows:

Hypothesis of functional utility and social-adjustive utility of the defunct brand have not associated with the participation in brand resurrection. These two Hypotheses have been rejected. On the other hand, value-expressive utility and perceived brand superiority of the defunct brand have positively associated with the participation in brand resurrection. The null hypotheses can not be rejected.

Nostalgia has positively moderate the relationship between (a) functional utility, (b) social-adjustive utility and (c) value-expressive utility and (d) participation in brand resurrection.

\section{DISCUSSION AND RESEARCH IMPLICATIONS}

The results of the study indicate that functional and social-adjustive utilities along with perceived brand superiority are not significantly associated with participation in brand resurrection. Further, we find partial support for the moderating effect of nostalgia. The relationship between functional and social-adjustive utilities and participation in brand resurrection is significant when moderated by nostalgia. An explanation could be made that nostalgia evokes a strong feeling of past experiences when the functional utility and social adjustive utility were important to individuals. For an increasing value of functional utility on the resurrection movement, company should offer good value for money (table 5.3) and try to be more trustworthy for the consumer. However, the increasing social- adjustive utility for the resurrection Movement, the marketers should build social self-image of the brand.

The relationship between value-expressive utility and participation in brand resurrection is significant. A possible explanation could be that value-expression is an environment-based, personality-based dynamic. In other words, consumers have long find the value-expressive utility of defunct brands relevant today. These findings provide evidence of the growing consumer pleasure after consuming this brand.

The significant interplay between the value-expressive utility and nostalgia also provides support to the notion that both intentional and unintentional factors can explain customer motivation to participate in brand resurrection, highlighting the need to better understand the role of unintentional factors in driving consumer behavior. The importance of understanding the interplay between the various utilities and nostalgia provides a more comprehensive framework for understanding customer motivations for participating in brand resurrection and may be useful for predicting the success of resurrected brands.

From a research standpoint, the importance of this study lies in the growing attention given to understanding the co-creation of brands in the area of brand revitalization (Dion D. a., 2016). Adding to the increased attention of co-creation in recent literature (Kennedy, 2016) understanding the co-creation elements of resurrecting defunct brands - killed given their past poor-performance -is critically important considering that the push to resurrect them is driven by a higher perceived value in the minds of the consumers compared to the organization. Specifically, the underlying notion in this context is that consumers are paving the way to bring back brands that were considered failures. Understanding the motivations driving the resurrection movements provides an insight into how the co-creation manifests in a consumer-brand context. 
Literature has also discussed retro branding (Brown S. K., 2003; Brown S. , 2015) the use of the previously well-known brand names, slogans, packages, etc., in an organization's current offerings. Point out that retro brands are on the rise, but the consumer perspective on these retro brands has largely been ignored. Finally, the result indicates that nostalgia positively moderates all factors like functional utility, social-adjustive utility, valueexpressive utility, and brand superiority of a brand towards the resurrection movement. In summary, this study provides a more comprehensive look at the factors that can determine brand resurrection in the Indian context.

\section{CONCLUSION}

It is important to note that all the brand resurrection have been started and driven by customers through customer-generated content. Organizations have for the most part assumed an uninvolved role in this value co-creation process. This is fundamentally determined by the concern that normally the interest for these dead brands is in mature as well as declining markets. Managers are doubtful about re-propelling brands in such markets, particularly, given the degree of rivalry and growth of these markets. In any case, there are different components that organizations ought to consider. All the more explicitly, organizations should focus on the planning of the brand re-launch, the degree of exposure, and publicity around the dead brand. On the off chance that enough energy has been made about the brand, the re-launch of the outdated brand has a decent possibility of being productive, even in a mature/declining market. The amount to be used to re-create an older brand surely need lesser amount than a new brand. Nostalgia may impact this procedure too by featuring the great time purchasers had with these old brands. For instance, Royal Enfield effectively re-propelled the brand when nostalgia, the discernments about the brand utilities, and brand predominance had accumulated enough momentum. In this manner, the planning of the brand re-dispatch could decide the job of sentimentality in shoppers' inclination for the outdated brands.

Another related dimension for bringing back defunct brands is the perception of brand superiority. Companies that are bringing back brands should be conscious about consumers' perceptions of brand superiority. If the defunct brand is already considered to be superior, it is better not to change the original brand features or core positioning. For example, KFC brought back its Chicken Littles on account of consumer demand. However, its sales failed to take off due to the perceived change in quality (Tuttle, 2015). Drawing parallel with the case of Classic Coke and New Coke, classics should better not be altered. On the other hand, Royal Enfield and Jawa successfully brought back their retro bike models with updated product features to suit the needs of the current consumers. Thus, consumer perceptions of brand utilities are influenced by the level of involvement and the type of product category. Despite its limitations, this study provides an initial exploration of brand resurrections in the Indian Context, an important and growing consumer-driven phenomenon.

\section{REFERENCES}

[1] Belk, R. (1991). Possessions and the Sense of past, Naturalistic Research from the Consumer Behavior.

[2] Bhat, S., \& Reddy, S. K. (1998). Symbolic and functional positioning of brands. Journal of Consumer Marketing, 15(1), 32-43. doi:10.1108/07363769810202664

[3] Brehm, J. (1966). A Theory of Psychological Reactance. Academic Press.

[4] Brown, S. (2015). When innovation met renovation: back to the future of branding. Marketing Intelience \& planning, Vol. 33 No. 5, pp. 634-655. 
[5] Brown, S. K. (2003). Teaching old brands new tricks: retro branding and the revival of brand meaning. Journal of Marketing, Vol. 67 No. 3, pp. 19-33.

[6] Cattaneo, E., \& Guerini, C. (2012). Assessing the revival potential of brands from the past: How relevant is nostalgia in retro branding strategies? Journal of Brand Management, 19, 680-687.

[7] Cohen, J. B. (2004). Affective Intuition and Task-Contingent Affect Regulation. Journal of Consumer Research, 31(2), 358-367. doi:10.1086/422114

[8] Davari, A., Iyer, P. and Guzmán, F. (2017), "Determinants of brand resurrection: Why consumers want dead brands back?", European Journal of Marketing, Vol. 51 No. 11/12, pp. 1896-1917. https://doi.org/10.1108/EJM-02-2016-0096

[9] Dimock, M. (2019, January 17). Defination generations:Where Millennials end Generation Z begins. Retrieved from www.pewresearch.org: http://www.pewresearch.org

[10] Dion, D., \& Mazzalovo, G. (2016). Reviving sleeping beauty brands by rearticulating brand heritage. Journal of Business Research, 69(12), 5894-5900. doi:10.1016/j.jbusres.2016.04.105

[11] Eagly, A. H., \& Chaiken, S. (1993). The psychology of attitudes. Fort Worth, TX: Harcourt Brace Jovanovich College Publishers.

[12] Ewing, M. J. (2009). Brand death: a developmental model of senescence. Business Research, Vol. 62 No. 3, pp. 332-338.

[13] Ewing, M. T., Jevons, C. P., \& Khalil, E. L. (2009). Brand death: A developmental model of senescence. Journal of Business Research, 62(3), 332-338. doi:10.1016/j.jbusres.2008.04.004

[14] Geiger-Oneto, S. G. (2013). Buying status' by choosing or rejecting luxury brand nd their counterfeits. journal of the academy of marketing science, 357-372.

[15] Grewal, R. M. (2004). The timing of repeat purchases of consumer durable goodsthe role of functional bases of consumer attitudes". Journal of Marketing Research, 101-115.

[16] Hirschman, E. C., \& Holbrook, M. B. (1982). Hedonic Consumption: Emerging Concepts, Methods and Propositions. Journal of Marketing, 46(3), 92. doi:10.2307/1251707

[17] Holak, Susan L. and Havlena, William J., (1998), Feelings, Fantasies, and Memories: An Examination of the Emotional Components of Nostalgia, Journal of Business Research, 42, issue 3, p. 217-226,

[18] Hsieh, Sara H. and Chang, Aihwa, (2016), The Psychological Mechanism of Brand Cocreation Engagement, Journal of Interactive Marketing, 33, issue C, p. 13-26,

[19] Iglesias, O., \& Bonet, E. (2012). Persuasive brand management. Journal of Organizational Change Management, 25(2), 251-264. doi:10.1108/09534811211213937

[20] Iglesias, O., Ind, N., \& Alfaro, M. (2013). The organic view of the brand: A brand value cocreation model. Journal of Brand Management, 20(8), 670-688. doi:10.1057/bm.2013.8

[21] jussi Rosendahi, T. F. (2017, May 31). Nokia relaunches iconic 3310 model in Finland. Retrieved from www.livemint.com: http://www.livemint.com

[22] Keller, K. (1993). Conceptualizing, measuring, and managing customer-based brand equity. journal of marketing, Vol. 57 No. 1, pp. 1-22.

[23] Keller, K. (2003). Brand synthesis: the multidimensionality of brand knowledge. journal of consumer research, Vol. 29 No. 4, pp. 595-600.

[24] Kennedy, E., \& Guzmán, F. (2016). Co-creation of brand identities: Consumer and industry influence and motivations. Journal of Consumer Marketing, 33(5), 313-323. doi:10.1108/jcm07-2015-1500 
[25] Kumar, N. (2003). Kill a brand, keep a customer. Harvard business review, Vol. 81 No. 12, pp. 86-95.

[26] Moye, J. (2018, August 6). paging All Surge Fans: "90s Cult Classic Now Available on Coca Cola Freestyle,Exclusively at Burger king. Retrieved from www.coca-colacompany.com: http://www.coca-colacompany.com

[27] O'Reilly, T. (2016). Zombie brands: under the influence. Retrieved december 15, 2016, from www.cbc.ca/radio/undertheinfluence/Zombia-brand:

http://www.cbc.ca/radio/undertheinfluence/Zombia-brand

[28] Puccinelli, N. G. (2015). Smiles lead to more smiles unless they lead to tears: a meta-analytic integration of affect effects",. Advances in consumer research, pp. 662-666.

[29] Schlossberg, M. (2015, August 12). Zombie retail brands are coming back from the dead. Retrieved September 01, 2020, from https://www.businessinsider.in/Zombie-retail-brands-arecoming-back-from-the-dead/articleshow/48460026.cms

[30] Stephen Brown, R. V. (2003). Teaching Old Brands New Tricks: Retro Branding and the Revival of Brand Meaning.

[31] Tesema, M. (2016, january 30). crystal pepsi is coming back to filfill your 90s dreams of seethrough soft drink. Retrieved from www.mashable.com: http//mashable.com

[32] Thompson, S. A., \& Sinha, R. K. (2008). Brand Communities and New Product Adoption: The Influence and Limits of Oppositional Loyalty. Journal of Marketing, 72(6), 65-80. doi:10.1509/jmkg.72.6.065

[33] Tuttle, B. (2015). "10 cult-favorite foods brought back from the dead by popular demand", Everyday Money. Retrieved January 28, 2016, from http://time.com/money/3756751/chickenfries-cult-favorite-fast-food

[34] Vallaster, C., \& Wallpach, S. V. (2013). An online discursive inquiry into the social dynamics of multi-stakeholder brand meaning co-creation. Journal of Business Research, 66(9), 15051515. doi:10.1016/j.jbusres.2012.09.012 